\title{
Jean Racine, Gli attaccabrighe
}

\section{Daniela Dalla Valle}

\section{(2) OpenEdition}

\section{Journals}

\section{Edizione digitale}

URL: http://journals.openedition.org/studifrancesi/8902

DOI: $10.4000 /$ studifrancesi.8902

ISSN: 2421-5856

\section{Editore}

Rosenberg \& Sellier

\section{Edizione cartacea}

Data di pubblicazione: 1 octobre 2008

Paginazione: 450

ISSN: 0039-2944

\section{Notizia bibliografica digitale}

Daniela Dalla Valle, «Jean Racine, Gli attaccabrighe», Studi Francesi [Online], 155 (LII | II) | 2008, online dal 30 novembre 2015, consultato il 09 janvier 2021. URL: http://journals.openedition.org/ studifrancesi/8902 ; DOI: https://doi.org/10.4000/studifrancesi.8902

\section{Questo documento è stato generato automaticamente il 9 janvier 2021.}

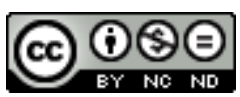

Studi Francesi è distribuita con Licenza Creative Commons Attribuzione - Non commerciale - Non opere derivate 4.0 Internazionale. 


\title{
Jean Racine, Gli attaccabrighe
}

\author{
Daniela Dalla Valle
}

\section{NOTIZIA}

JEAN RACINE, Gli attaccabrighe, a cura di G. DAVICO BONINO, Macerata, Liberilibri, 2006, pp.

95.

1 Les Plaideurs non sono certo una delle opere più commentate e analizzate di Racine; Guido Davico Bonino ha deciso di tradurla elegantemente in italiano, corredando il testo di alcune note e di un'agile prefazione, che mette a punto la commedia raciniana nella vita e nella carriera dell'autore. è una buona occasione per i lettori italiani di avvicinarsi a un'opera poco nota e da noi mai rappresentata. 